\title{
Islamic Inheritance Law For Economic Social Justice in Indonesia
}

\author{
Dewi Sukarti \\ State Islamic University Syarif Hidayatullah \\ Jakarta, Indonesia \\ dewi.sukarti@uinjkt.ac.id
}

\author{
Isnawati Rais \\ State Islamic University Syarif Hidayatullah \\ Jakarta, Indonesia
}

\begin{abstract}
Islamic inheritance Law offers an economic social justice for Moslems within a nuclear family, through both consanguineous neal and affinal relationships. Based on a qualitative research on women's inheritance, this article explores the concept of social economic justice in Islamic inheritance law. This article found that Islamic inheritance law offers better economic social justice compared to patrilineal or matrilineal customary laws that prioritize certain heirs. In addition, the Compilation of Islamic Law (Kompilasi Hukum Islam) gives conjugal property rights to both husband and wife enabling husband and wife share equal portion of property. However, the rest of the rules of the Kompilasi adopt fiqh in which shares of women and men are different.
\end{abstract}

Keywords-Islamic Inheritance Law; Social Economic Justice; Kompilasi Hukum Islam;

\section{INTRODUCTION}

This article explores the concept of social economic justice within Islamic inheritance law. Social economic justice in inheritance law means that all the closest relatives of the deceased have rights to the deceased's legacy in the form of inheritance shares. Farther relatives and orphans who need property may also receive portions of the legacy in the form of bequest.

Inheritance is an old tradition of the world. It has existed even since pre-Islamic times. In Pre-Islamic Arab, inheritance law was designed to consolidate the strength of tribe in the tribal warfare. Shares of inheritance were for heroes who were successful in battle field. Those Arabian culture was recorded in a hadith that described the reason for the revelation of QS.4:11. The hadith was related by At-Tirmizi, Abu Daud, Ibnu Majah and Ad-Daru Quthniy from Jabir ibn Abdullah: 'From Jabir, he said, that the wife of Sa'ad ibn Rabi' informed the Prophet that Sa'ad was killed at the battlefield of Uhud along with You). He was survived by two daughters and a brother. His brother had taken all his properties, whereas a girl cannot get married without any properties. At that time the Prophet did not say a word. At another time she came again to the Prophet and said: O Prophet! How are the two daughters of Sa'ad? The Prophet replied: Bring Sa'ad's brother to me. Upon the coming of the brother of Saad, the Prophet said to him: Give the two daughters of Saad two thirds (2/3) and to his widow one eight (1/8). The rest is for you. In another source this is the factor of the revelation of the verse 12 of Surah anNisa" (Qurtubi, 1995: 57; Sabiq, 1977: 424).

The pre-Islamic Arabian culture of inheritance was patrilineal. Rights of inheritance belonged solely to the male agnate relatives (asaba) of the deceased to keep property within the tribe (Coulson, 1991: 15-16). Compared to such an Arabian tradition of inheritance that gave portions of inheritance only to knights and heroes who won battle fields for their clan's pride and gave bequest to clan for their pride while leaving members of close relatives in destitute (Zuhayli, 1989: 7), Islamic law of inheritance introduced novel rules of inheritance, viz. close relatives (by consanguinity and affinity), although they are females and children; and novel rules of bequest, namely to zawil arham.

In Indonesia, some ethnic groups practice the concept of patrilineal inheritance, while the other groups practice the concept of matrilineal inheritance. In a patrilineal society, according to Hacker, women's access to (economic) resources and their ability to bequeath their property as they wish are severely restricted (Hacker, 2010: 328). Patrilineal societies in Indonesia, such as Batak, Besemah, and Lampung, do not acknowledge females as heirs and inheritors. The institutional reasons for the norm are that firstly, in terms of production a woman is never the one who control or own the means of production. Secondly, a wife only functions as a seedbed to enlarge her husband's clan (Irianto, 2012: 109). Only after the Indonesian Supreme Court's verdict of 1961 (judge made law) women in patrilineal communities have the right to their fathers' properties, and in migration situation the concept of joint property is known that enables a woman of a patrilineal community to inherit or receive the conjugal property (Irianto: 110; Ihromi, 1994: 535). 
In contrast, in matrilineal culture, like Minangkabau and Semendo, males are neither heirs nor inheritors. According to Minangkabau's matrilineal culture, the husband has no real power over his wife nor the father over his children. The man's children are not his heirs. His goods will belong to his sister's descendants (Prins, 1951: 297). This matrilineal culture has pushed many Minangkabau men to migrate outside West Sumatra (Chadwick, 1991: 70).

Another matrilineal culture in Indonesia exists in Semendo in South Sumatra. In Semendo's culture exists the adat tunggu tubang. Tunggu or tungguan means watching over a place and being in charge of certain matters. Tubang means lineage. The eldest daughter, after marriage is destined to become the tunggu tubang (Barendregt: 117).

After being a tunggu tubang, the eldest daughter and her husband guard the main heirlooms, such as the central house, a communal rice field, and a fish pond (pauk). A tunggu tubang does not own the heirlooms but the usufruct rights to them. At the same time, she is responsible for the fate of the lineage and they must serve the lineage members who come to ask for their share of the yield. If a lineage member cannot harvest at his rice field, he can ask the tunggu tubang to temporarily use the tunggu tubang rice field (Barendregt: 118).

The governance of tunggu tubang works as follows: the tunggu tubang daughter and her husband run daily errands. For the inspection of lineage's heirlooms, the tunggu tubang is helped by lineage elders at a meeting called apit jurai. Members of apit jurai assembly are the tunggu tubang daughter's eldest brother (called the ahli jurai pandas), her maternal uncle (the former ahli jurai, called jenang), the grandmother of the current tunggu tubang (the hinghest ahli, called the payung jurai, the lineage's umbrella). The assembly discuss current lineage affairs and solve the problem hoping for agreement among the members. Although the other brothers are also called ahli, but they are not dominant in lineage matters (Barendregt: 119-120). This matrilineal culture has also pushed Semendo's men migrate outside their Semendo land.

Compared to patrilineal inheritance traditions and matrilineal traditions, which are gender biased, Islamic inheritance law is fairer to both men and women.

\section{ISLAMIC INHERITANCE LAW}

\section{A. Quranic Injunctions of Inheritance}

Quran says that Islamic law of inheritance is obligatory. Such rule of obligation of complying the Islamic inheritance law is laid down by Surah Annisa verse 12: [This is] an ordinance from Allah, and Allah is the All Wise and Forbearing.

\section{B. Consanguinal and Affinal Relationships as the Bases of Inheritance}

In verses 11 and 12 of Surah An-Nisa' Allah shortlists whom have rights to inheritance, i.e. those who have relationship, either by consanguinity (nasab) or by affinity (mushaharah), with the deceased. Those of consanguineous relatives are parents, children, brother, sister, uncle, aunt, grandparents; while those of affinal relatives are wife and husband.

Verse 11 of Surah An-Nisa lays rules on children and parents as heirs. "Allah instructs you concerning your children: for the male, what is equal to the share of two females. But if there are [only] daughters, two or more, for them is two-thirds of one's estate. And if there is only one, for her is half. And for one's parents, to each one of them a sixth of his estate if he left children. But if he had no children and the parents [alone] inherit from him, then for his mother is one-third. And if he had brothers [or sisters], for his mother is a sixth, after any bequest he [may have] made or debt."

While verse 12 of Surah Annisa lays rules on husband and wives as heirs." And for you (husband) is half of what your wives leave if they are survived by no child. But if they are survived by a child, for you is one-fourth of what they leave, after any bequest they [may have] made or debt. And for the wives is one-fourth if you are survived by no child. But if you are survived by a child, then for them is one-eighth of what you leave, after any bequest you [may have] made or debt. And if a man or woman is survived neither by ascendants nor descendants but by a brother or sister, then for each one of them is a sixth. But if they are more than two, they share onethird, after any bequest which was made or debt, as long as there is no block. [This is] an ordinance from Allah, and Allah is the All Wise and Forbearing.

These rules are germane to how Islam pay attention to, and anticipate, the near relatives left by the inheritor living in broke and in poverty. In legal perspective, inheritance is regarded as the consideration for duties of protection and support owed to the deceased during his lifetime, so that the stronger the family bond, the greater the right of inheritance (Coulson, 1971:3).

\section{Bequest for Farther Relatives and Orphans in Need of Property}

Bequest institution is an old tradition of many nations. But the implementation of pre-Islamic bequest was not fair, for example a man bequeathed all his wealth to anybody out of his family that he wanted to, and avoided his child and close relatives to inherit his wealth, as prevailed in Roman society. Nomadic Arabian people also behaved similarly, they bequeathed all of their personal estates to the other people for their personal pride and left their relatives in poverty (Zuhayli, 1989: 7).

Then Islam came and continues the institution of bequest, but changes the rule by taking into account the principle of justice and prioritize parents and near relatives. In Surah AlBaqarah (2) verse 180 is ruled: "It is prescribed for you when death is coming to any one of you, if he leaves much wealth that he makes a will to parents and near relatives to act with fairness; it is an obligation on those who fear God)."

In a sermon during the farewell pilgrimage (hajj wada), the Prophet said: "In fact Allah has given to all owners their rights, then there is no will for heirs" (Shaukani, n.d: 151). Wills can be taken advantage to give property to farther relatives who are not among zawil furud, i.e. zawil arham or 
adopted child or orphaned child who is in need of such property.

Secondly, the amount of bequeathed wealth is less than one third to maximum one third. as is said in a hadith: The Prophet PBUH said to Saad ibn Abu Waqqas who wanted to bequeath two thirds or a half of his wealth to his only daughter. Saad ibn Abu Waqqas responded to the prophet's statement: "one third?" The Prophet said again: and one third is much. In fact, it is better for you to leave your heirs being wealthy than to leave them in poverty that become the other people's dependencies" (Shaukani: 148).

\section{ISLAMIC INHERITANCE LAW IN INDONESIA: THE COMPILATION OF ISLAMIC LAW}

The Compilation of Islamic Law is material for settling cases in Religious Courts in Indonesia. The contents of the Compilation are marriage law in book 1 and inheritance law in book 2 .

Article 174 (1) of book 2 of the Compilation of Islamic Law states that groups of heirs are both consanguineal and affinal heirs. Letter (a) of article 174 verse 1 rules that according to consanguineal relationship, male heirs are: father, sons, brothers, uncles, grandfather; female heirs consist of : mother, daughters, sisters, aunts, and grandmother. In letter (b) this article rules that according to affinal relationship, heirs are widower or widow. At verse (2) the article affirms that if all the aforementioned heirs exist, the heirs entitled to inheritance are: sons and daughters, father, mother, widows and widower.

The shares that each heir would receive are in accordance with Islamic law of inheritance. However, in article 183, after all the heirs know their shares in the estate they may agree on peaceful settlement on their inheritance. This article enables the equal portion among the male and female heirs should all the heirs agree.

What is unique in the Kompilasi is article 190 on conjugal property between husband and wives. According to this article, wives have the rights to a part of conjugal property, and all the entitlements of each wife would be the rights of her heirs. The concept of conjugal properties in the Kompilasi is influenced by Javanese customary law which is bilateral in nature. The bilateral values prevailed in Javanese culture are mirrored in almost every element of family matters, including property gained during the marriage. This old custom of equality of husband and wife implies that the Muslim regulation about the husband's duty to provide his wife with daily food, clothing and housing during the marriage and 'iddah period cannot be well understood by Javanese society since it is ancient to their culture (Prins, 1951: 290-291).

As a result of the bilateral culture, Javanese customary law of inheritance is also bilateral. Husband and wife are heirs to each other and their children are heirs to both father and mother. The conjugal property also comes from Javanese culture. On the death of her husband, the Javanese widow is entitled to a portion, a half or third, of the family property. The widow's share is theoretically equivalent to her contribution to the family property. She also retains her own individual property (barang asal), which her children will eventually inherit. After the widow's share, the rest of the property is for the children or if there are no children for the next of husband's kin. The children also inherit the individual property of the deceased father. If there are no children on their deaths, the individual properties of the husband and wife return to their respective parents or siblings. But on the death of the husband, the property is retained by the widow so long as she does not remarry for she has a right to use both types of property for her support. The property division usually occurs after widow also died, unless she and the heirs agree to divide it earlier (Lev, Spring 1962: 214).

Although article 190 of the Compilation of Islamic Law acknowledges the equal portion between husband and wife in conjugal property, the rests of rules within the Compilation are not synchronized. As a result, the other articles on inheritance still give bigger portion to husband and sons than to wife and daughters. This unsynchronized rules must be understood as a mixture of fiqh and adat. Judges of Religious Courts solve this problem by complying to figh for the rights of children, parents, brothers and sisters; and complying to adat (that which has been adopted by the compilation) for the rights of husband and wife. After separation of conjugal rights, husband and wife inherit to each other. Thus a wife shall receive a half of the conjugal property and $1 / 4$ (if there is no child) or $1 / 8$ (if there is a child) of the deceased husband's legacy, including his share of the conjugal property.

Another unique feature in the Kompilasi is the rule on adopted child and adopted parents. Article 209 (1) rules that the legacy of adopted child is distributed in accordance with Articles 176 to 193, meaning that the adopted son/daughter are treated as the real children to their real consanguineal relatives. As for the adopted parents who are not bequeathed are given compulsory bequest (wasiat wajibah) $1 / 3$ of the property of their adopted son/daughter. Verse (2) of this article rules that to the adopted son/daughter who are not given bequest are given compulsory bequest of $1 / 3$ of their adopted parents' property.

Another different feature in the Compilation is article 185 on representation of heirs as surrogate heir. This rule is against all classical fiqh books (Nurlaelawati, n.y: 105).

\section{CONCLUSIONS}

Islamic law of inheritance offers economic and social justice to all Muslims individually regardless of seniority and gender. Close relatives either by consanguinity or affinity are prioritized to get accessed to the deceased's property. Orphans and farther are possible to receive portions of legacy in the form of bequest.

In Indonesia, the Compilation of Islamic Law legalizes the customary law of conjugal property that equalize the share of husband and wife; adopted parents and adopted children can access the property through the institution of bequest or compulsory bequest, and representation of heirs. 


\section{REFERENCES}

[1] Al-Qurtubi, al-Jami 'Li Ahkam al-Qur'an. Beirut-Lubnan: Daarul Ihyaa' at-Taurats al-'Arabiy, 1416H/1995) Juz V, 1995, p. 57.

[2] Al-Shaukani, Nail al-Awtar, (NP: Dar al-Fikr, n.d) Juz 6, pp. 148, 151.

[3] Bart Barendregt, From the Realm of Many Rivers: Memory, Places, and Notions of Home in the Southern Sumatran Highlands, Leiden: Unpublished PhD Thesis, pp. 117-120.

[4] Daniel S. Lev, Lev, Daniel S. The Supreme Court and Adat Inheritance Law in Indonesia", in The American Journal of Comparative Law, Vol. 11, No. 2, (Spring, 1962), p. 214.

[5] Dephan Hacker, "The Gendered Dimensions of Inheritance: Empirical Food for Legal Thought", Journal of Empirical Legal Studies, Volume 7, Issue 2, June 2010, h.328.

[6] Jan Prins, "Adat Law and Muslim Religious Law in Modern Indonesia: An Introduction" in Die Welt des Islams, New Series, Vol. 1, Issue 4 (1951), pp. 290-297.

[7] N.J. Coulson. A History of Islamic Law, Edinburgh: Edinburgh University Press, 1991, pp. 15-16.

[8] N.J. Coulson. Succession in the Muslim Family, New York: Cambridge University Press, 1971, p. 3

[9] R.J. Chadwick, "Matrilineal Inheritance and Migration in A Minangkabau Community "in Indonesia, No. 51, (Apr. 1991), p. 70.

[10] Sayyid Sabiq, Figh al-Sunnah,Beirut: Daar al-Fikr, 1397H/1977, Ed. I, Juz III, p. 424.

[11] Sulistyowati Irianto, "The Changing Socio Legal Position of Women in Inheritance: A Case Study of Batak Women in Indonesia", in Yoko Hayami, Junko Koizumi, Chalidaporn Songsamphan, and Ratana Tosakul (Eds.), The Family Influx in Southeast Asia: Institution, Ideology, Practice, Kyoto: Kyoto University Press, 2012, pp. 109-110.

[12] T.O. Ihromi, "Inheritance and Equal Rights for Toba Batak Daughters", in Law \& Society Review, Vol. 28, No. 3, (1994), p. 535.

[13] Wahbah al-Zuhayli, Figh al-Islam wa Adillatuhu, (Damaskus: Dar al-Fikr, 1409 H/1989 M ), juz VIII, p. 7. 